How to cite this article:

Akram, F., Abrar ul Haq, M., \& Raza, S. (2018). Corporate Governance and Firm's Environmental Performance: A Moderating Role of Institutional Regulations. International Journal of Management Studies, 25(2), 19-37.

\title{
A ROLE OF CORPORATE GOVERNANCE AND FIRM'S ENVIRONMENTAL PERFORMANCE: A MODERATING ROLE OF INSTITUTIONAL REGULATIONS
}

\author{
FARHEEN AKRAM \\ MUHAMMAD ABRAR-UL-HAQ \\ AMA International University of Bahrain
}

SAQLAIN RAZA

Member of Chamber of Commerce and Industry Multan, Pakistan

*Corresponding Author: saqlainraza1983@hotmail.com

\begin{abstract}
Climate change has become one of the biggest issue across the globe as most countries have been bearing the consequences of this phenomenon on a global scale. Countries have been drafting environmental regulations to help mitigate the environmental pollution caused by climate change. Therefore, the implications of environmental policies in various sectors of the economy are dependent on state regulations. The main objective of this study is to investigate the impact of corporate governance on environmental performance. Furthermore, this study examines the impact of institutional regulations on the relationship of corporate governance and firms' environmental performance. The data was collected from the top 120 manufacturing companies that are based in Pakistan, India, China and Bangladesh. The binary logit regression methodology was employed in this study. The results indicate that the attributes of corporate governance have a positive and significant impact on green performance. In addition, the results were also positive and significant on the moderating role of institutional regulation for corporate governance and firm performance. Hence, based on the empirical findings, this study recommends strict environmental institutional regulations to further enhance environmental performance.
\end{abstract}


Keywords: Green performance, Corporate governance, Environment, Institutional policies.

Received: 1/10/2018 Revised:31/3/2019 Accepted: 20/08/2019 Published: 15/12/2019

\section{Introduction}

Environmental protection has been a key agenda in many countries around the world to mitigate the effects of climate change. These long - term fluctuations in climate are due to mass pollution, emissions of carbon dioxide and harmful gasses, and other direct or indirect human activities. Human beings have been destroying the environment while fulfilling their basic needs. Hence, to reduce the effects of climate change, countries have designed and implemented several eco-friendly policies, such as the Kyoto Protocol, carbon taxes, Paris Agreement and schemes of emission trading. Tricker (2009) stated that the changes in institutional policies have reshaped the landscape for business competition and included these environmental issues in the strategic goals of corporations. Ortiz-de-Mandojana, AguileraCaracuel and Aragón-Correa (2010) suggested that bold and creative reforms in governing bodies, and corporate governance structures and practices are needed to meet current environmental challenges.

The role of corporate governance in an organization is well discussed and globally accepted. Generally, the literature on corporate governance were centered on various control, monitoring and principal-agent problems. However, the implications of corporate governance on environmental policies have not been completely elucidated (Berrone \& Gómez-Mejia, 2009). A recent study suggested that corporate governance does have a significant influence on the adoption of active environmental policies (Walls, Berrone \& Phan, 2012; Ortiz-de-Mandojana et al., 2010). According to Berrone and GómezMejia (2009), eco-friendly corporate governance strategies must be geared towards the environment and allocate any environmental related issues to a specific committee. Moreover, various literature have supported this notion that corporate governance structure and strategies have positively influenced environmental related decisions (Dixon-Fowler, Ellstrand \& Johnson, 2017; Berrone \& Gómez-Mejía, 2009; Huang, Lobo \& Zhoul, 2009).

The need for eco-friendly corporate strategies have become crucial in tackling the challenges of environmental pollution. However, 
evidences were brought forth that have shown big businesses frequently violating the environmental protection laws (Jang, Park, Roh \& Han, 2015). Such actions from these organizations have led to various problems such as the emission of harmful gasses, large financial cost, labor injuries, disabilities, illness, and even death. These factors have not only affected the employees, but have also been carried forward to the customers. Most organizations tend to make decisions, particularly with regards to industrial waste product, with less consideration of the environment.

Corporate governance play a major role in the decision making process of any organization, which can be observed through the organizations' financial performance and social behavior. Unfortunately, there are very limited grounding theories of corporate governance, especially with respect to the effects of corporate governance on environmental performance. In the absence of a definitive theory, (Walls et al., 2012) employed a fact-based research methodology to explore the relationship between corporate governance and environmental performance. It was identified that a large number of organizations have performed with lesser or greater environmental friendly behaviors when compared to the requirements of the governing mechanism. Hence, this suggests that the degree of variation and the motives for corporate behavior are broader than expected. Certain existing regulatory strategies that are focused on compliance have failed to facilitate reward or encourage beyond compliance behavior (Amore \& Bennedsen, 2016). Moreover, the compliance of environmental policies are affected by the institutional regulations in a country as the compliance of corporate governance on eco-friendly policies are insufficient.

Additionally, a recent study have tested the moderating role of institutional regulations on the relationship between corporate governance and environmental performance (Ortiz-de-Mandojana, Aguilera-Caracuel \& Morales-Raya, 2016). However, this study was limited to developed countries, and the data employed in this study was more than a decade old. The regulations for corporate governance on the environment are constantly changing. Consequently, the decades old statistics are not appropriate to conclude that institutional regulations have affected the environmental performance specifically in developing countries. Moreover, researchers have been using different moderator variables to identify the changes in relationship 
between the independent and dependent variables (Nouri, Sanayei, Fathi, Kazemi \& Soltani, 2016). Hence, this study investigates the relationship between corporate governance and corporate environmental performance. Furthermore, this study examines the moderating role of institutional regulations between corporate governance and corporate environmental performance. Data was collected from the top 120 manufacturing companies from four Asian countries, which are Pakistan, China, Bangladesh and India. This study applied Binary Logit Model to test the proposed model.

The structure of the remaining paper is divided into five sections. In section two, literature is discussed based on the hypotheses constructed. Section three outlines the method of data collection and measurement of the variables. Section four presents the statistical findings. Section five presents a discussion on the results. Finally, section six concludes the limitations and provide suggestions on future research.

\section{Literature Review and Hypotheses Development}

\section{Corporate Governance}

With regards to corporate governance and its influence on environmental safety, the core element of corporate governance is the directors that play an active role in all decision-making processes in organizations. For instance, directors are part of the corporate board that have the power to decide on operational and strategic agendas of the firm. Every decision made on strategies and operations, including those that involve environmental issues, would pass through the corporate board (Aguilera \& Jackson, 2003). Therefore, as the central decision-making authority, corporate boards are responsible for environmental strategies for the firm, and subsequently these strategies must be proactively enforced (Ortiz-de-Mandojana et al., 2016). Due to high regulatory pressure, it has become common practice in organizations to have a separate committee that deals with environmental issues (Dixon-Fowler et al., 2017; Babiak \& Trendafilova, 2011). These committees are also known as corporate social responsibility committee. Moreover, diversity (with regards to independent directors, foreign directors or others) within the corporate board is an asset to organizations, whereby these individuals will be able to develop and enforce efficient environmental policies (Villiers, 
Naiker \& van Staden, 2011). The role of the board of directors are extremely relevant in tackling environmental concerns. (Villiers et al., 2011) proposed that a less diverse, large, and independent board of directors would restrict the environmental performance of the organization. The complexities of a large and independent board weakens their ability of effective monitoring and information processing, however, these hurdles can be minimized by focusing on a small and diverse board.

In addition, Tauringana and Chithambo (2015) suggested that board size is associated with the diverse knowledge from each board members, and further implied that board size significantly influences the dispersion of environmental information in firms. The extent and depth of boardroom discussions on environmental issues determine the quality of environmental strategies and policies within the firm. The quality of environmental policies are also affected by the presence of foreign directors, as directors from another country would exhibit different management skills and knowledge of environmental policies from various other countries (Aguilera-Caracuel \& Ortizde Mandojana, 2013). Foreign directors could play an important part in the preparation of new environmental policies which have already been implemented in other countries within the firm. The probability of lawsuits due to violation of environment policies is essentially dependent on the attitude of the corporate board towards the environment (Aguilera-Caracuel \& Ortiz-de Mandojana, 2013). Hence, to identify the determinants of environmental litigation, this study focuses on the corporate board as the core decision making unit within firms that are involved in shaping corporate environmental policies. This study used three important proxy variables of corporate governance that are closely linked with the environmental strategies implication. As such, the following hypothesis is presented:

Hypothesis 1a: Delegating the environmental responsibilities to an environmental committee will positively influence the environmental performance.

Hypothesis 1b: Highly independent board will positively influence the environmental performance.

Hypothesis 1c: More diverse board, in terms of nationality, will positively influence the environmental performance. 


\section{Institutional Regulations}

According to the "quiet life" argument proposed by Bertrand and Mullainathan (2003), when executives are not exposed to the disciplining role of takeovers, they will tend to extract personal rent by undertaking fewer initiatives that require major managerial effort and organizational changes. This statement bridges the gap between green innovation and corporate governance as the current process of research and development within organizations have significantly changed and has demanded changes within the organizational structure. The requirements of the "going green" phenomenon is complex and demands highly innovative and unique methods that are only possible with a current and knowledgeable research and development department (Ortiz-de-Mandojana et al., 2016). Moreover, Koc Santalò and Diestre (2012) argued that, "successfully reducing and preventing waste emissions necessitates a great deal of extra managerial effort because it requires a complex redesign of a firm's internal processes and the development of green competencies". Similarly, the OECD reported that, "the most important factor in preventing firms from taking a more radical approach to ecoinnovation and aiming for systemic shifts would be that even more progressive businesses remain unconsciously aligned to and locked into conventional business models. Many companies are comfortable with their existing business models and not ready to leverage the crucial systemic changes that are needed for radical innovation".

The effectiveness of the corporate governance structure towards the adoption of proactive environmental friendly policies and behavior are significantly dependent on the national institutional context. In this regard, Aguilera and Jackson (2003) have stated that the institutions hold high importance to corporate governance. Consequently, past literature have indicated that the social responsibility behavior of organizations are closely linked to the institutional pressure for environmental stability (Aguilera-Caracuel et al., 2013; Berrone, Fosfuri, Gelabert \& Gomez-Mejia, 2013). The authors have concluded that the firms' tendency to be involved in environmental innovations are high when regulatory pressure from the institutions are high.

Furthermore, the study carried out by (Delmas \& Montes-Sancho, 2010) suggested that environmental regulations at the national level persuaded firms to initiate eco-friendly programs. Additionally, the study conducted by (Sullivan, 2009) investigated the effects of the influence from national regulations on the reduction of greenhouse 
gas emission. Delmas (2002) stated that the implications of the ISO 14001 standards had varied across borders as it was dependent on the national environmental policies. Specifically, in the case of multinational companies, these companies would be located and operate in various countries, where each unit's environmental policies would need to adapt according to the host country's regulations (Aguilera-Caracuel et al., 2013). Consequently, different units of the same multinational organization would enjoy cost benefits of low environmental protection in the countries for which the established environmental protection policies are weak. Therefore, the following hypothesis are stated as follows:

Hypothesis 2: The probability of good environmental performance is dependent on the institutional regulations of the country where the firm is operating.

Hypothesis 3a: Institutional regulations can significantly moderate the relationship between the environmental committee and environmental performance.

Hypothesis 3b: Institutional regulations can significantly moderate the relationship between independent directors and environmental performance.

Hypothesis 3c: Institutional regulations can significantly moderate the relationship between foreign directors and environmental performance.

\section{Conceptual Framework}

The literature have concluded that the decision making authority is an inherited element of corporate governance which is performed by the corporate board. From the literature review, the most prominent concept of corporate governance is the agency theory (Ross, 1973), however, this theory is limited and does not justify the importance of environmental issues for strategic goals. The main assumption behind agency theory revolves around the problems faced by the agency, for which most of the organizations face due to the separation of ownership and management (Ross, 1973). Other organizational paradigms for corporate governance and firm performance are based on the primacy of shareholders. The various theories on corporate governance, such as agency theory and stewardship theory have 
highlighted the issues of performance, particularly the performance of top management and their interest. There have not been any provision on the environmental performance and social performance of the organizations in these theories (Walls et al., 2012). However, the main assumptions of the institutional theory are related to the current study. Therefore, this study incorporates institutional theory (Scott, 1987) as organizations are required to operate and interact with the external factors such as governments, society and different cultures. The integration of external factors develop and reshape the organizational structure and practices. Hence, the institutional policies of a country does have a significant effect on the adoption of environmental practices and social behavior of organizations. However, there are limited studies conducted that considered the role of institutional regulations on environmental performance (Walls et al., 2012). For instance, if strict environmental regulations were drafted and enforced in a country, corporate governance structure of the organization will induce corporate social responsibility within the organizations by establishing committees that will oversee corporate environmental policies. Consequently, if environmental policies are flexible in a country, the corporate board will find ways or loopholes to avoid the enforcement of such policies in order to save cost. Hence, with regards to the fact based arguments of Walls et al. (2012), this study proposed that the institutional regulations moderate the relationship between corporate governance and environmental performance.

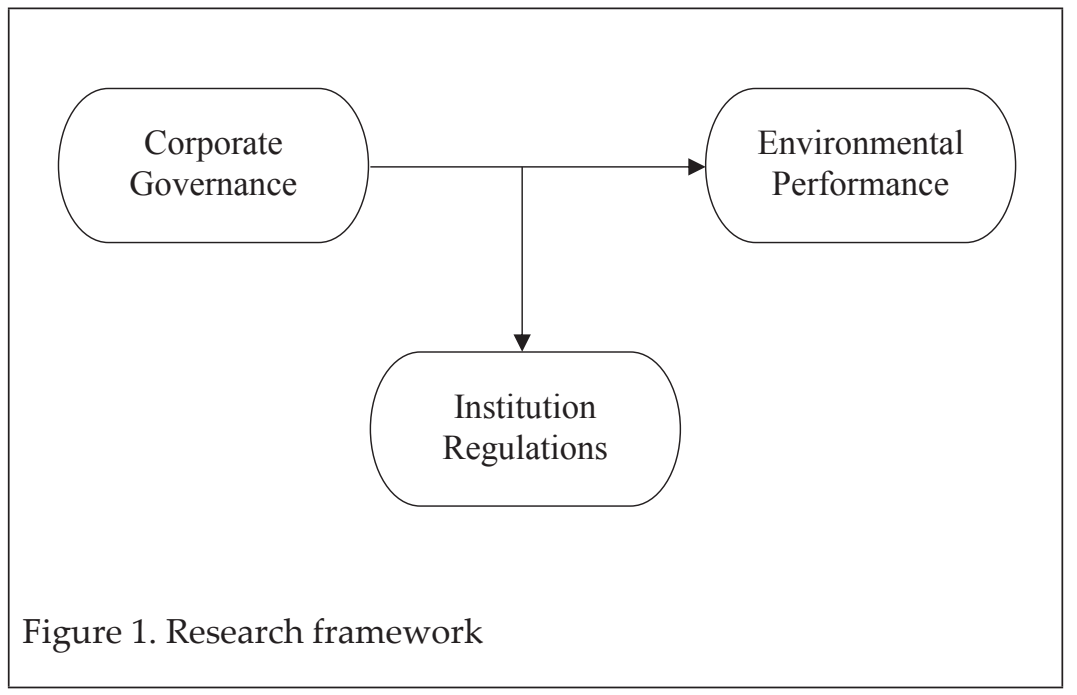




\section{Methodology}

The data collected for this study were companies of the manufacturing sector that are selected from four Asian countries (i.e. Pakistan, India, China and Bangladesh), as these countries are currently at the same stage in the implementation of environmental regulations (Jang et al., 2015). Moreover, the corporate structure and governance mechanism of the sample selected countries are similar, and therefore reduces the chance for data heterogeneity and potential outliers. The data from the top 120 manufacturing companies were collected from the selected countries (30 top companies from each country) for the year 2017. Market capitalization was used as a measure to determine the top companies from each country. The manufacturing sector was selected for empirical analysis as this sector has been a key component of the economy in all selected countries.

\section{Measurement of Variables and Collection of Data}

The dependent variablefor this study is theenvironmental performance of the organizations and is measured through dichotomous variable, as suggested in the study by (Ortiz-de-Mandojana et al., 2016). The variable is assigned a value of 1 if the firm is involved in producing green products in the year 2017, or it will be assigned the value of 0 if the firm does not produce any green products.

On the other hand, the independent variable is corporate governance and is measured through three proxy variables. These variables are chosen due to their potential influence on environmental performance and is subjected to the availability of data as only a few firms have provided detailed information on their corporate governance structure and financial disclosure. The first proxy is the environmental committee or corporate social responsibility committee and is assigned the value of 1 if it is present in an organization, otherwise it is assigned a value of 0 . A second proxy variable is the number of independent directors which is measured as the percentage of outside directors to board size. Data related to this variable are extracted from annual reports from the selected companies. The third proxy of corporate governance used in this study is the existence of international directors on the board of directors. This variable is measured as the proportion of international directors on the board to 
board size. Information on this variable was obtained from the annual reports of the firms.

Institutional regulations for environmental protection are measured as the score for ecosystem vitality of the country. Ecosystem vitality is a measure deduced from the effects of industrialization and urbanization and is recorded in the Environmental Performance Index 2017. Ecosystem vitality includes several indicators (Water Resources, Agriculture, Forests, Fisheries, Biodiversity \& Habitat, Climate \& Energy) that determines the state of the environment. This study defines institutional regulations as an independent and moderator variable between corporate governance and green performance. Furthermore, this study employs three control variables, namely firm size, firm financial performance and leverage in empirical analysis. Firm size is measured as the log of total assets of organization and accurate measurements were obtained from the year-end value of the assets. The data related to assets are collected from the balance sheet of the respective firms.

Profitability of the organization can affect its behavior towards the adoption of environmental policy. Therefore, the profitability of the organization is a control variable employed in this study. Profitability is measure of the return on an assets, which has been frequently cited in literature as an indicator of a company's financial performance. This study also controls the firm's leverage which is obtained by dividing total liabilities to total assets. Firm's leverage can limit the firms' intention to make eco-friendly investment decisions, as firms may use the additional funds to fulfill their debts.

\section{Econometrics Model}

The econometrics model of the study is as follows;

\section{Model 1}

Environmental Perforance $=\alpha+\beta_{1}$ Envcom $+\beta_{2}$ Inddir $+\beta_{3}$ Fordir $+\mu$

\section{Model 2}

Environmental Perforance

$$
\begin{aligned}
& =\alpha+\beta_{1} \text { Envcom }+\beta_{2} \text { Inddir }+\beta_{3} \text { Fordir }+\beta_{4} \text { Envcom } * \text { Instreg }+\beta_{5} \text { Inddir } \\
& * \text { Instreg }+\beta_{6} \text { Fordir } * \text { Instreg }+\mu
\end{aligned}
$$




\section{Results and Discussion}

To eliminate potential outliers from the data, this study applied a data trimming technique proposed by Cox (2013). Trimming is a method used to reduce highly scattered values from the data. After data trimming, descriptive statistics of the data was carried out. The results of the descriptive statistics are shown in Table 1.

Table 1

Data Characteristics

\begin{tabular}{lcccc}
\hline Countries & Ind_dir & For_dir & $\begin{array}{c}\text { Number of } \\
\text { Companies having } \\
\text { Environment } \\
\text { committee }\end{array}$ & $\begin{array}{c}\text { Score of } \\
\text { EPI }\end{array}$ \\
\cline { 2 - 5 } Pakistan & 3 & Mean & 19 & 14 \\
China & 3 & 2 & 27 & 2 \\
Bangladesh & 2 & 2 & 26 & 23 \\
India & 3 & 3 & 21 & 20 \\
\hline Note: Env_com: Environment Committee, Ind_dir: Independent Director, For_dir: \\
Foreign Directors, EPI: Environment Performance Index
\end{tabular}

The results show that the average number of independent directors on the corporate board is 2 to 3 members in 2017. The number of foreign directors on the corporate board for selected companies are 2 to 3 members in the sample countries. The environmental committee is measured as the dichotomous variable and therefore, the mean value is not examined. The number of companies with an environmental committee from the sample countries are presented in Table 1. China has the majority number of environmental committees which are present in 27 companies. However, the EPI score for China is the lowest as compare to other countries which indicates that the environmental regulations in China are insufficient despite their hard efforts to attain environmental sustainability.

This study applied a binary logit model to test the proposed hypotheses. Binary logit model is considered as the most appropriate technique to be utilized when the dependent variable is a dichotomous variable, where its value lies between 0 and 1 . Table 2 presents the correlation between the variables. 
IJMS 25 (2), 19-37 (2018)

Table 2

Correlation Matrix

\begin{tabular}{llllllll}
\hline & Env_com & Ind_dir & For_dir & Inst_reg & Firm_size & Profi & Lever \\
\hline Env_com & 1 & & & & & & \\
Ind_dir & $0.546^{* * *}$ & 1 & & & & & \\
For_dir & $0.328^{* *}$ & $0.314^{* * *}$ & 1 & & & & \\
Inst_reg & $0.157^{*}$ & $0.102^{*}$ & $0.133^{*}$ & 1 & & & \\
Firm_size & $0.250^{* *}$ & 0.041 & $0.265^{* *}$ & $0.112^{*}$ & 1 & & \\
Profi & $0.528^{* * *}$ & $0.183^{*}$ & $0.420^{* * *}$ & $0.517^{* * *}$ & $0.614^{* * *}$ & 1 & \\
Lever & $-0.200^{* *}$ & $0.302^{* *}$ & $-0.192^{* *}$ & -0.069 & $0.221^{* *}$ & $-0.335^{* *}$ & 1 \\
\hline
\end{tabular}

* significant at $10 \%$, ${ }^{* *}$ significant at $5 \%$ and ${ }^{* * *}$ significant at $1 \%$

Note: Env_com: Environment Committee, Ind_dir: Independent Director, For_dir: Foreign Directors, Inst_reg: Institutional Regulations, Firm_size: Firm Size, Profi: Profitability, Lever: Leverage

The results for the binary logit regression are shown in Table 3. By utilizing the econometrics model, two models were designed and examined in this study. Model 1 includes the independent and control variables, while Model 2 was develop to identify the relationship between the variables. The results of Model 1 indicate that the environmental committee, independent directors, foreign directors and institutional regulations have a positive and significant influence on green performance. The results between the control variables show that profitability has a positive and significant effect on green performance, however, leverage has a negative but significant impact on green performance. Furthermore, the results from Model 1 suggest that the probability for green performance is high with the existence of an environmental committee as the relationship between these factors are significant at the $1 \%$ level of significance, with an Odd ratio of 1.065. Based on these results, hypothesis 1a is accepted. Moreover, these results are in line with those from previous studies (Ortiz-deMandojana et al., 2016; Walls et al., 2012) as scholars have claimed that delegating environment responsibilities to a specific committee increases the environmental performance of the firms. Consequently, environmental committees are only responsible for policies that involve environmental issues and therefore, it is crucial for executives to communicate effectively on issues regarding environmental friendly policies. By doing so, the environmental committee would be able to positively affect the environmental performance (Walls et al., 2012) 
IJMS 25 (2), 19-37 (2018)

Table 3

Binary Logit Regression

\begin{tabular}{lcc}
\hline & Odd Ratio Model 1 & Odd Ratio Model 2 \\
\hline Env_com & $1.065^{*}$ & $1.157^{*}$ \\
Ind_dir & $1.104^{* *}$ & $1.007^{* *}$ \\
For_dir & $1.087^{*}$ & $1.259^{*}$ \\
Inst_reg & $1.509^{*}$ & $1.155^{*}$ \\
Firm_size & $1.297^{*}$ & $1.195^{*}$ \\
Profi & $1.138^{*}$ & $1.248^{*}$ \\
Lever & 0.328 & $0.886^{*}$ \\
Env_com* Inst_reg & & $1.015^{*}$ \\
Ind_dir* Inst_reg & & $1.221^{*}$ \\
For_dir* Inst_reg & & $1.302^{*}$ \\
Intercept & 223.026 & 219.917 \\
\hline -2 Log likelihood & 437.225 & 573.151 \\
Cox \& Snell R Square & 0.305 & 0.385 \\
Nagelkerke R Square & 0.386 & 0.461 \\
Chi-square & 221.724 & 253.227 \\
*** significant at 10\%, & & \\
Note: Env_com: Environment Committee, Ind_dir: Independent & Director, For_dir: \\
Foreign Directors, Inst_reg: Institutional & Regulations, Firm_size: & Firm Size, Profi: \\
Profitability, Lever: Leverage & &
\end{tabular}

To answer hypothesis $1 \mathrm{~b}$, the results of the binary regression analysis indicates that the relationship between independent directors and green performance is positive and statistically significant at $5 \%$ level of significance. The Odd ratio of independent directors is 1.104, which implies that a minor change in the percentage of independent directors would lead to a higher green performance probability. The results are in line with the findings from Ortiz-de-Mandojana et al. (2016), Walls et al. (2012), as a positive relationship between independent directors and environmental performance was observed in these studies. In addition to the similarities of these findings, the authors from previous studies concluded that independent directors do not have the required knowledge on the firms' internal structure which subsequently worsens environmental performance. However, Slawinski (2012) argued that the independent directors monitor 
the board's performance, but are much more concerned with the expectations from stakeholders. Therefore, independent directors can positively influence the environmental performance of organizations. Another possible reason for this positive relationship is that the selected countries are developing countries, and that most of the independent directors are from developed countries. These directors would eventually bring in more environmental friendly agendas to the board and encourage the board to adopt more eco-friendly policies.

Similarly, the relationship between foreign directors and firms' green performance is positive and statistically significant at $1 \%$ significance level (Odd ratio is 1.087). Hence, hypothesis 1c is accepted, and concludes that the probability for eco-friendly products is higher under the management of foreign directors. The direct relationship between institutional regulations and green performance is positive and significant at $1 \%$ level of significance, with Odd ration valued at 1.509. Thus, hypothesis 2 is accepted, and asserts that the probability for green performance is high in countries where the institutional regulation on the environment are strict. The relationship between foreign directors and environmental performance is rarely investigated in previous studies. However, due to the large number of foreign direct investments in developing countries, the percentage of directors from foreign countries have increased significantly. The empirical results indicate that foreign directors are an important part of the organization as they are able to contribute positively towards environmental performance. Moreover, foreign directors are more concerned about their presence and reputation, in the international context. Hence, they are able to provide more eco-friendly ideas that may have been implemented by other companies in their own country. Foreign directors from different countries bring a variety of unique ideas to cope with environmental issues. Other than that, the direct relationship between institutional regulations and environmental performance is positive and significant, with Odd ratio at 1.509 which also implies that strict environmental policies that are established in countries will affect the social behavior within the organization.

The results of Model 2 indicates that the hypothesis $3 a, 3 b$ and $3 c$ is positive and significant at $1 \%$ level of significance, with Odd ratios at 1.015, 1.221 and 1.302 respectively. These findings assert that institutional regulations moderate the relationship of the environmental committee, independent directors and foreign 
directors with the firms' green performance. Additionally, these results suggest that in the presence of stringent environmental regulations in a country, the environmental committee works harder and effectively to avoid law suits (Ortiz-de-Mandojana et al., 2016). Moreover, independent directors have gained more information on environmental regulations as they have been involved in more than one corporate boards, which enables them to put forth unique ideas to tackle environmental issues. With regards to foreign directors, they are more patriotic towards their own country, and while having to manage their large share of ownership may prompt foreign directors to avoid risks when pursuing corporate policies in accordance to the countries' laws. With the inclusion of the interaction effects in Model 2, the Odd ratios for the direct relationships between variables reported in Model 1 show a minor change and confirms the significant effect of moderation in this study.

\section{Conclusion and Recommendations}

This paper have concluded that environmental performance is becoming a prime agenda for all governments across the globe. Governments have introduced several policies to cope with the challenges of climate change and environmental pollution. Hence, various sectors of the economy have been under pressure to implement environmental friendly policies. Several studies have been conducted to investigate the influence of decision-making bodies and organizations on the implementation of eco-friendly policies that could improve environmental performance. Previous literature have concluded that environmental performance is affected by the structure of corporate governance and institutional regulations. Corporate governance is defined as the decision-making body of an organization, and is responsible in determining strategic goals and agendas that could affect the organizational performance in various aspects including environmental performance. With the inclusion of governments and other institutions, the eco-friendly behavior of organizations does have a significant influence on environmental performance. Previous studies stated that the governance structure have influenced the social behavior of organizations. However, these studies are subjected to several theoretical and practical limitations. Due to the limitations from previous literature, this study empirically tested a model which included a pivotal variable (institutional regulations) that have often been ignored in past studies. 
The findings from this study have indicated a positive effect between environmental committee and the firms' green performance. This suggests that delegating the responsibility of environmental issues to a specific board of committee will enhance the firms' ability to produce more green products. An organization's environmental committee should consist of directors with a specialization in ecology, whereby these directors are responsible to monitor and uphold the ISO 14001 standards within the organization. Furthermore, the results have also shown a positive correlation between countries that have strict environmental regulations and the effectiveness of environmental committees to comply with the requirements of these regulations.

The role of independent directors in green performance was found to be positive in this study. Moreover, the moderating effect of institutional regulations is positive for the relationship between independent directors and firm performance. Hence, hypotheses $1 \mathrm{~b}$ and $3 \mathrm{~b}$ were accepted. The significance of these relationships indicate that in order to create a good and sustainable image in an organization, independent directors would enforce more eco-friendly ideas to protect the organization's image in public. Independent directors monitored the firms' environmental standards with respect to institutional regulations without considering the cost, which subsequently led to an increase in the green performance of the companies. Additionally, the results concluded that the presence of foreign directors increased the green productivity of organizations. The binary regression output carried out in this study provided support for the acceptance of hypotheses $1 \mathrm{c}$ and $3 \mathrm{c}$. Foreign directors were found to have diverse information on green management and policies from various countries which have acted as guidelines for organizations to implement. Due to the huge investments in organizations, foreign directors are more concerned with lawsuits and penalties that may result due to negligence or violation of these environmental regulations. Therefore, foreign directors would persuade corporate boards to impose more eco-friendly policies.

\section{Limitations and Future Research Suggestions}

Although this paper has provided several important findings and have contributed to the existing literature, there are still some limitations that can be considered for future research. This study only included data from the manufacturing sector due to the limited data availability and the difficulty to manually record data from 
annual reports. Therefore, future research can be conducted on other sectors of the economy. Moreover, other proxy variables of corporate governance such as female directors and ownership structure that includes foreign ownership can be further investigated in future research.

\section{References}

Aguilera, R. V., Jackson G. (2003). The cross-national diversity of corporate governance: Dimensions and determinants. Academy of Management Review, 28(3), 447-465, DOI: 10.5465/ AMR.2003.10196772

Aguilera-Caracuel J, Ortiz-de-Mandojana N. (2013). Green innovation and financial performance: An institutional approach. Organization \& Environment, 26(4), 365-385, DOI: $10.1177 / 1086026613507931$

Amore, M. D., \& Bennedsen, M. (2016). Corporate governance and green innovation. Journal of Environmental Economics and Management, 75, 54-72.

Babiak, K., Trendafilova, S. (2011). CSR and environmental responsibility: Motives and pressures to adopt green management practices. Corporate Social Responsibility and Environmental Management, 18, 11-24, DOI: 10.1002/csr.229

Berrone, P., Fosfuri A, Gelabert, L., Gomez-Mejia, L. R. (2013). Necessity as the mother of 'green' inventions: Institutional pressures and environmental innovations. Strategic Management Journal, 34(8), 891-909, DOI: 10.1002/smj.2041.

Berrone, P., Gómez-Mejía, L. R. (2009). Environmental performance and executive compensation: An integrated agencyinstitutional perspective. Academy of Management Journal, 52(1), 103-126, DOI: 10.5465/AMJ.2009.36461950

Bertrand, M., \& Mullainathan, S. (2003). Enjoying the quiet life? Corporate governance and managerial preferences. Journal of Political Economy, 111, 1043-1075.

Cox, N. J. (2013). Speaking Stata: Trimming to taste. The Stata Journal, 13(3), 640-666.

De Villiers, C., Naiker, V., \& Van Staden, C. J. (2011). The effect of board characteristics on firm environmental performance. Journal of Management, 37(6), 1636-1663.

Delmas, M. A., Montes-Sancho, MJ. (2010). Voluntary agreements to improve environmental quality: Symbolic and substantive cooperation. Strategic Management Journal, 31(6), 575-601, DOI: $10.1002 / \mathrm{smj} .826$ 
Delmas, M. A. (2002). The diffusion of environmental management standards in Europe and the United States: An institutional perspective. Policy Sciences, 35(1), 91-119, DOI: 10.1023/A: 1016108804453

Dixon-Fowler, H. R., Ellstrand, A. E., \& Johnson, J. L. (2017). The role of board environmental committees in corporate environmental performance. Journal of Business Ethics, 140(3), 423-438.

Huang H., Lobo G., Zhou J. (2009). Determinants and accounting consequences of forming a governance committee: Evidence from the United States. Corporate Governance: An International Review 17(6): 710-727, DOI: 10.1111/j.1467-8683.2009.00769.

Jang, E. K., Park, M.S., Roh, T. W., \& Han, K. J. (2015). Policy instruments for eco-innovation in Asian countries. Sustainability, 7(9), 1258612614.

Kock, C. J., Santalò J. \& Diestre L. (2012). Corporate governance and the environment: What type of governance creates greener companies? Journal of Management Studies 49, 492-514.

Nouri, B. A., Sanayei, A., Fathi, S., Kazemi, A., \& Soltani, M. (2016). Designing a model for the relationship between marketing activities and organization performance: Meta-analysis on the moderating role of research topic characteristics. International Journal of Management Studies, 23(2), 1-26.

Ortiz-de-Mandojana, N., Aguilera-Caracuel, J., Aragón-Correa J. (2010). The adjustment of the corporate governance structures to global sustainability. In Global Sustainability as a Business Imperative (pp. 127-146). Palgrave Macmillan, New York.

Ortiz-de-Mandojana, N., Aguilera-Caracuel, J., \& Morales-Raya, M. (2016). Corporate governance and environmental sustainability: The moderating role of the national institutional context. Corporate Social Responsibility and Environmental Management, 23(3), 150-164.

Ross, S. A. (1973). The economic theory of agency: The principal's problem. The American Economic Review, 63(2), 134-139.

Scott, W. R. (1987). The adolescence of institutional theory. Administrative Science Quarterly, 493-511.

Slawinski, N. E. K. (2012). Short on time: The role of organizational time orientation in business sustainability. Retrieved from https://www.researchgate.net/publication/276051270_Short_ on_time_The_role_of_time_in_business_sustainability

Sullivan, R. (2009). The management of greenhouse gas emissions in large European companies. Corporate Social Responsibility and Environmental Management, 16(6), 301-309, DOI: 10.1002/csr.187 
IJMS 25 (2), 19-37 (2018)

Tauringana, V., \& Chithambo, L. (2015). The effect of DEFRA guidance on greenhouse gas disclosure. The British Accounting Review, 47(4), 425-444.

Tricker, B. (2009). Corporate governance: Principles, policies and practices. Oxford University Press: New York.

Walls, J. L., Berrone, P., \& Phan, P. H. (2012). Corporate governance and environmental performance: Is there really a link? Strategic Management Journal, 33(8), 885-913. 